\title{
Analysis of zinc oxide nanoparticles binding proteins in rat blood and brain homogenate
}

This article was published in the following Dove Press journal:

International Journal of Nanomedicine

15 November 2014

Number of times this article has been viewed

\author{
Kyu Hwan Shim' \\ John Hulme' \\ Eun Ho Maeng ${ }^{2}$ \\ Meyoung-Kon $\mathrm{Kim}^{3}$ \\ Seong Soo A An' \\ 'Department of Bionano \\ Technology, Gachon Medical \\ Research Institute, Gachon \\ University, Sungnam-si, Gyeonggi-do, \\ South Korea; ${ }^{2}$ Department of \\ Analysis, KTR, Kimpo, Gyeonggi-do, \\ South Korea; ${ }^{3}$ Department of \\ Biochemistry and Molecular Biology, \\ Korea University Medical School \\ and College, Seoul, South Korea
}

Correspondence: Seong Soo A An

Department of Bionano Technology,

Gachon Medical Research Institute,

Gachon University, Sungnam-si,

Gyeonggi-do, 46I-70I, South Korea

Tel +82 3। 7508755

Fax +82 3I 7508755

Email seongaan@gachon.ac.kr

Meyoung-Kon Kim

Department of Biochemistry and

Molecular Biology, Korea University

Medical School and College,

Anam-Dong $5 \mathrm{Ga}$, Seoungbuk-Gu,

Seoul I35-70I, South Korea

Tel +82 29206184

Fax +82 29230480

Email jerrykim@korea.ac.kr

\begin{abstract}
Nanoparticles (NPs) are currently used in chemical, cosmetic, pharmaceutical, and electronic products. Nevertheless, limited safety information is available for many NPs, especially in terms of their interactions with various binding proteins, leading to potential toxic effects. Zinc oxide $(\mathrm{ZnO}) \mathrm{NPs}$ are included in the formulation of new products, such as adhesives, batteries, ceramics, cosmetics, cement, glass, ointments, paints, pigments, and supplementary foods, resulting in increased human exposures to $\mathrm{ZnO}$. Hence, we investigated the potential $\mathrm{ZnO}$ nanotoxic pathways by analyzing the adsorbed proteins, called protein corona, from blood and brain from four $\mathrm{ZnO} \mathrm{NPs}, \mathrm{ZnO}^{\mathrm{SM} 20(-)}, \mathrm{ZnO}^{\mathrm{SM} 20(+)}, \mathrm{ZnO}^{\mathrm{AE} 100(-)}$, and $\mathrm{ZnO}^{\mathrm{AE} 100(+)}$, in order to understand their potential mechanisms in vivo. Through this study, liquid chromatography-mass spectroscopy/ mass spectroscopy technology was employed to identify all bound proteins. Totals of 52 and 58 plasma proteins were identified as being bound to $\mathrm{ZnO}^{\mathrm{SM} 20(-)}$ and $\mathrm{ZnO}^{\mathrm{SM} 20(+)}$, respectively. For $\mathrm{ZnO}^{\mathrm{AE} 100(-)}$ and $\mathrm{ZnO}^{\mathrm{AE} 100(+)}, 58$ and 44 proteins were bound, respectively. Similar numbers of proteins were adsorbed onto $\mathrm{ZnO}$ irrespective of size or surface charge of the nanoparticle. These proteins were further analyzed with ClueGO, a Cytoscape plugin, which provided gene ontology and the biological interaction processes of identified proteins. Interactions between diverse proteins and $\mathrm{ZnO}$ nanoparticles could result in an alteration of their functions, conformation, and clearance, eventually affecting many biological processes.
\end{abstract}

Keywords: brain homogenate, nanotoxicity, plasma, protein corona

\section{Introduction}

Nanoparticles (NPs) are found in numerous household items and are manufactured in large quantities worldwide. ${ }^{1}$ Recently increased exposures to NPs through cosmetics, medicine, and food products may have direct influences on human health and life. However, all known NPs and their impacts on human health are yet to be compiled.

Zinc oxide $(\mathrm{ZnO})$ NPs are exceedingly common in numerous products, such as adhesives, batteries, ceramics, cosmetics, cement, ferrites, glass, lubricants, ointments, paints, pigments, sealants, tire rubber, and supplementary foods. Recently, ZnO NPs were also employed in diverse products for applications in biosensors, cell imaging, drugs, and nanomedicine. ${ }^{2}$ Previous trials with NPs indicated that they could be absorbed through the skin, respiratory tract, or intestine in daily life; moreover, significant accumulations were found in tissues, including lung, kidney, and liver. ${ }^{3}$ Circulating NPs could interact with diverse biological molecules in blood and specific tissues, such as the lymph nodes, pancreas, and other glandular bodies for causing toxic effects. 
Several studies reported the cytotoxicity of ZnO NPs in various cell lines in vitro. For example, after an exposure of $\mathrm{ZnONPs}(50 \mu \mathrm{g} / \mathrm{mL})$, human aortic endothelial cells exhibited approximately $50 \%$ cell death. ${ }^{4}$ All human mesothelioma and rodent fibroblasts cells died after an exposure to $\mathrm{ZnO}$ NPs (19 nm in size at $15 \mu \mathrm{g} / \mathrm{mL}$ ). ${ }^{5}$ Gene expressions were altered after exposure to NPs in in vitro and in vivo experiments. ${ }^{6,7}$ Moreover, ZnO NPs induced slight cytotoxic effects to human T-cells at $5 \mathrm{mM}$, and strong toxic effects towards human cancer T-cells. ${ }^{8}{ }^{89}$ In cases of dermal exposures, ZnO NPs did not induce any skin irritation, but they induced phototoxicity. ${ }^{10}$ Other studies suggested a potential link between neurodegenerative diseases and the neurotoxic effects of $\mathrm{ZnO} .{ }^{11} \mathrm{In}$ mouse neuroblastoma cells, ZnO NPs (50 nm in size at $50 \mu \mathrm{g} / \mathrm{mL}$ ) caused 50\% cell death. ${ }^{12}$ Moreover, $\mathrm{ZnO}$ NPs decreased the cell viability of human neural cells by $50 \%$ and also induced apoptosis of neural stem cells. ${ }^{13,14}$ Finally, silver, copper, or aluminum NPs approximately $50-60 \mathrm{~nm}$ in size were able to disrupt the blood-brain barrier (BBB) of an in vivo system and aggravate the brain pathology, suggesting that these NPs may have disrupted BBB directly and penetrated into the brain. ${ }^{15}$

Recently, the physicochemical properties of NPs, such as surface charge, size, shape, hydrophobicity, and catalytic activity, were considered with regard to their deterministic influences towards nanotoxicity. The toxic profiles of NPs seemed to vary according to their physicochemical properties, such as surface charge, size, and shape; NPs of $20 \mathrm{~nm}$ in size revealed higher toxicity than larger sized NPs. ${ }^{16-18}$ Hence, the problem of in vitro methods in nanotoxicity assessment have been widely discussed, as the various features of NPs may interfere with assay components or even with the detection systems. ${ }^{19}$ For the above reasons, it was necessary that the properties of the NPs should be characterized in detail before assessing their toxicity. Furthermore, the assessment should be performed independently according to the physicochemical properties of the NPs. Interestingly, recent studies showed that physicochemical properties of NPs could be altered by different surrounding conditions, such as different buffers as well as blood and cell culture media. In other words, the toxicity of NPs could be affected by changes in surface chemistry or through agglomeration with other NPs in cell culture media. ${ }^{20}$ These influences on NPs from the surrounding media supports the similar view that the properties of NPs could be altered via agglomeration or from interactions with other proteins upon circulation, which could vary depending on the individual's age, sex, tissue type, as well as the specific biological activities of the proteins. The interactions between NPs and proteins could lead to altered protein-protein/ligand responses. For example, silica NPs may disrupt the enzyme activity through unfolding of critical regions. ${ }^{21}$ Moreover, NPs may enhance protein fibrillation, causing many diseases such as Alzheimer's disease and dialysis-related amyloidosis. ${ }^{22}$ In order to understand the physicochemical properties of $\mathrm{ZnO}$ NPs in the blood stream, those bound proteins or protein coronas onto the surface of ZnO NPs should be identified and characterized for their properties and roles with regard to NPs, and their pathways and toxicological mechanisms should be estimated.

In this paper, both cationic and anionic $\mathrm{ZnO}$ NPs of two different sizes (20 and $100 \mathrm{~nm}$ ), $\mathrm{ZnO}^{\mathrm{SM} 20(-)}, \mathrm{ZnO}^{\mathrm{SM} 20(+)}$, $\mathrm{ZnO}^{\mathrm{AE} 100(-)}$ and $\mathrm{ZnO}^{\mathrm{AE} 100(+)}$, were used to assess bound proteins in blood plasma and brain for their potential role(s) and perturbations in various biological activities by surface modifications.

\section{Material and methods Preparation of nanoparticles} $\mathrm{ZnO} \mathrm{NPs}, \mathrm{ZnO}^{\mathrm{SM} 20(-)}, \mathrm{ZnO}^{\mathrm{SM} 20(+)}, \mathrm{ZnO}^{\mathrm{AE} 100(-)}$ and $\mathrm{ZnO}^{\mathrm{AE} 100(+)}$, were chosen to represent charge and size effects of nanoparticles, as suggested by KFDA (Ministry of Food and Drug Safety) for toxicological reports to OECD (Organisation of Economic Co-operation and Development). The reasons for the selection of $\mathrm{ZnO} N P s$ and their characterizations are discussed in the other manuscripts in the supplement issue. ${ }^{23}$ Different sizes of $\mathrm{ZnO}$ nanomaterial were purchased from Sumitomo Osaka Cement Co, Ltd (Lot number 141319 for $20 \mathrm{~nm}$ ) (Tokyo, Japan) and American Elements (Lot number 1871511079-673 for $100 \mathrm{~nm}$ ) (Los Angeles, CA, USA). The surface charge of the $\mathrm{ZnO}$ NPs was modified with citrate (for negative charge), and L-serine (for positive charge), as reported previously. ${ }^{23}$ The physicochemical properties were verified, including average size, morphology, and zeta potential. ${ }^{23}$

\section{Plasma and brain homogenate preparation}

Rat plasma samples were collected in a sodium/heparin anticoagulant tube to prevent blood clotting and were centrifuged for 30 minutes at $850 \times g$ to separate the plasma from blood cells. The supernatant (plasma) was transferred, aliquoted, and stored at $-80^{\circ} \mathrm{C}$.

Whole brain was obtained from adult rat immediately after euthanasia. For immunohistochemistry, the left hemisphere of the brain was stored in formalin at $4^{\circ} \mathrm{C}$. For brain homogenate $(\mathrm{BH})$, the right hemisphere of the brain was homogenized with phosphate buffered saline and ceramic beads with Hybaid RiboLyser (Hybaid Ltd., Ashford, UK) to 
make a $10 \%(\mathrm{w} / \mathrm{v})$ solution, and aliquoted into $2 \mathrm{~mL}$ tubes. Afterwards, the $\mathrm{BH}$ was centrifuged to remove any large particulates and the supernatant was stored at $-80^{\circ} \mathrm{C}$.

\section{Incubation of $\mathrm{ZnO}$ NPs with the plasma and $\mathrm{BH}$}

$\mathrm{ZnO}^{\mathrm{SM} 20(+)}$ and $\mathrm{ZnO}^{\mathrm{AE} 100(+)}$ were diluted in L-Serine/ (4-(2-hydroxyethyl)-1-piperazineethanesulfonic acid) (HEPES) buffer (10\% L-Serine, 20 mM HEPES; pH 6.2). $\mathrm{ZnO}^{\mathrm{SM} 20(-)}$ and $\mathrm{ZnO}^{\mathrm{AE} 100(-)}$ were diluted in citrate/HEPES $(10 \%$ sodium citrate, $20 \mathrm{mM}$ HEPES; $\mathrm{pH}$ 7.3). The stated solutions were centrifuged for 10 minutes at 10,000 rpm, and the supernatant was removed. Rat plasma or $\mathrm{BH}$ was added and the solutions were incubated for 1 hour at $37^{\circ} \mathrm{C}$. After incubation, the solution was centrifuged for 10 minutes at $10,000 \mathrm{rpm}$ then washed (3 times) with $1 \mathrm{~mL}$ phosphate buffered saline. Afterwards, the bound proteins on the $\mathrm{ZnO}$ NPs were analyzed using liquid chromatography-mass spectroscopy/mass spectroscopy (LC-MS/MS) with the method described in previous report (Kyu Hwan Shim, personal communication, 2014). LC-MS/ MS was performed by Diatech Korea Co, Ltd (Seoul, South Korea). In brief, bound proteins were eluted by boiling the solution, and then digested in sodium dodecyl sulphate polyacrylamide gel electrophoresis 1D gel with trypsin. The cleaved peptides were detected using a LC-MS/MS and analyzed by comparing the fragmentation patterns and their respective masses. The acquired liquid chromatography-electrospray ionization-tandem mass spectrometry (LC-ESI-MS/MS) fragment spectra were searched in the BioWorksBrowser ${ }^{\mathrm{TM}}$ (version Rev 3.3.1 SP1; Thermo Fisher Scientific, Waltham, MA, USA) with the SEQUEST search engines against nonredundant Mus musculus database (August 20, 2008 version) at National Center for Biotechnology Information (http://www. ncbi.nlm.nih.gov/). The consensus score (10.15) was used for selection criteria as that score was within $1 \%$ of false discovery rate from our simulation experiment.

\section{ClueGO}

Cytoscape (National Institute of General Medical Sciences, Bethesda, MD, USA) is a powerful software program used to visualize relationships between proteins or genetic interactions. The Cytoscape plugin, ClueGO (Cordeliers Research Center, Paris, France), allowed analysis of gene ontology and biological processes in concert with other interacting proteins. ClueGO was downloaded from http://apps. cytoscape.org/apps/cluego. ClueGO was accessed through the plugins menu. After starting ClueGO, a selection panel appeared on the left side of Cytoscape. ClueGO analyzed both single genes and comparisons of clusters, supporting several organisms with different identifier types. A simple text format enabled the import of external data. ClueGO used precompiled files, such as GO, KEGG, and BioCarta, to increase the speed of ClueGO analysis. Statistical tests were used to calculate the $P$-value and the significance of each group. Moreover, it was possible to regulate network types from detailed networks to global networks. The global network simplified the biological processes by adjusting the significance of particular genes. In contrast, the detailed network displayed very specific interacting processes. After starting functional analysis, ClueGO displayed the visualized network interactions, an information table for associated genes, a significance histogram of each group, as well as a chart overview of the functional groups.

\section{Results}

Proteins from the protein corona of plasma and $\mathrm{BH}$ were identified and classified according to their affinity for ZnO NPs (Table 1). The number of plasma proteins within the criteria, above a score of 10.15, implied no significant difference irrespective of the ZnO's size or surface charge. A broader range of proteins from the $\mathrm{BH}$ tended to bind to the larger $\mathrm{ZnO}$ NPs rather than to the smaller ZnO NPs. Remarkably, more proteins from the $\mathrm{BH}$ bound to the $\mathrm{ZnO}$ NPs than did proteins from the plasma.

The degree of similarity was compared among the bound proteins to four types of $\mathrm{ZnO}$ NPs in plasma and $\mathrm{BH}$ (Tables 2 and 3). In the case of plasma, about $50 \%$ of proteins were bound to both $\mathrm{ZnO}^{\mathrm{SM} 20(+)}$ and $\mathrm{ZnO}^{\mathrm{SM} 20(-)}$. For the $100 \mathrm{~nm}$ $\mathrm{ZnO}$ NPs, approximately $45 \%$ of the proteins were bound to the differently charged particles. Twenty-six percent and $34 \%$ of proteins bound to $\mathrm{ZnO}^{\mathrm{SM} 20(-)}$ and $\mathrm{ZnO}^{\mathrm{AE} 100(-)}$, respectively. $\mathrm{ZnO}^{\mathrm{SM} 20(+)}$ and $\mathrm{ZnO}^{\mathrm{AE} 100(+)}$ had $42 \%$ and $38 \%$ of similarity, respectively. Unlike plasma, brain proteins exhibited different

Table I The total number of bound proteins on the surface of $\mathrm{ZnO}$, according to different ZnO NPs types by sizes and charges

\begin{tabular}{|c|c|c|c|c|c|}
\hline Diameter & Samples & Charge & $\begin{array}{l}\text { Total } \\
\text { proteins }\end{array}$ & $\begin{array}{l}\text { Within } \\
\text { criteria }\end{array}$ & $\begin{array}{l}\text { Outside } \\
\text { of criteria }\end{array}$ \\
\hline \multirow[t]{4}{*}{$20 \mathrm{~nm}$} & Plasma & + & 203 & 52 & $|5|$ \\
\hline & & - & 253 & 58 & 195 \\
\hline & Brain & + & 249 & 172 & 77 \\
\hline & homogenate & - & 404 & 294 & 110 \\
\hline \multirow[t]{4}{*}{100 nm } & Plasma & + & 211 & 58 & 153 \\
\hline & & - & 156 & 44 & 112 \\
\hline & Brain & + & 442 & 315 & 127 \\
\hline & homogenate & - & 450 & 339 & 111 \\
\hline
\end{tabular}

Abbreviations: NPs, nanoparticles; $\mathrm{ZnO}$, zinc oxide. 
Table 2 The ratio of similarity of plasma protein coronas compared with different types of $\mathrm{ZnO}$ NPs

\begin{tabular}{|c|c|c|c|}
\hline Characteristics & $\begin{array}{l}\text { Total } \\
\text { proteins }\end{array}$ & $\begin{array}{l}\text { Common } \\
\text { proteins }\end{array}$ & $\begin{array}{l}\text { Similarity } \\
\text { (\%) }\end{array}$ \\
\hline \multicolumn{4}{|l|}{ Charge } \\
\hline $\mathrm{ZnO}^{\mathrm{SM} 20(+)}$ & 52 & 29 & 56 \\
\hline $\mathrm{ZnO}^{\mathrm{SM} 20(-)}$ & 58 & & 50 \\
\hline $\mathrm{ZnO}^{\mathrm{AE} \mid 00(+)}$ & 58 & 23 & 40 \\
\hline $\mathrm{ZnO}^{\mathrm{AE} \mid 00(-)}$ & 44 & & 52 \\
\hline \multicolumn{4}{|l|}{ Size } \\
\hline $\mathrm{ZnO}^{\mathrm{SM} 20(-)}$ & 58 & 15 & 26 \\
\hline $\mathrm{ZnO} \mathrm{AE}^{\mathrm{A} \mid 00(-)}$ & 44 & & 34 \\
\hline $\mathrm{ZnO}^{\mathrm{SM} 20(+)}$ & 52 & 22 & 42 \\
\hline $\mathrm{ZnO}^{\mathrm{AE} \mid 00(+)}$ & 58 & & 38 \\
\hline
\end{tabular}

Abbreviations: NPs, nanoparticles; $\mathrm{ZnO}$, zinc oxide.

degrees of similarity in binding to differently charged $20 \mathrm{~nm}$ $\mathrm{ZnO}$ NPs, with $81 \%$ determined to have bound to $\mathrm{ZnO}^{\mathrm{SM} 20(+)}$ and $47 \%$ determined to have bound to $\mathrm{ZnO}^{\mathrm{SM} 20(-)}$, respectively. On the other hand, $100 \mathrm{~nm} \mathrm{ZnO}$ NPs shared approximately $70 \%$ fractions of brain protein between both $\mathrm{ZnO}^{\mathrm{AE} 100(-)}$ and $\mathrm{ZnO}^{\mathrm{AE} 100(+)}$. According to size dependency of NPs, 52\% of proteins were bound to $\mathrm{ZnO}^{\mathrm{SM} 20(-)}$, whereas $45 \%$ of proteins were bound to $\mathrm{ZnO}^{\mathrm{AE} 100(-)}$. The commonly bound proteins to both $\mathrm{ZnO}^{\mathrm{SM} 20(+)}$ and $\mathrm{ZnO}^{\mathrm{AE} 100(+)}$ from brain homogenates were about $45 \%$. Interestingly, the similarity ratio between the two sizes was less than that between the different surface charges, indicating that the type of protein adsorbed to NPs may be more dependent on size than on surface charge. However, we cannot rule out that various proteins may have different adsorption to different types of NPs. These discordances of bound proteins could perturb various biological activities and processes.

Proteins within criteria for each respective ZnO NPs in Table 1 were further analyzed with one of Cytoscape plu-

Table 3 The ratio of similarity of $\mathrm{BH}$ protein coronas compared with different types of $\mathrm{ZnO}$ NPs

\begin{tabular}{|c|c|c|c|}
\hline & $\begin{array}{l}\text { Total } \\
\text { proteins }\end{array}$ & $\begin{array}{l}\text { Common } \\
\text { proteins }\end{array}$ & $\begin{array}{l}\text { Similarity } \\
(\%)\end{array}$ \\
\hline \multicolumn{4}{|l|}{ Charge } \\
\hline $\mathrm{ZnO} \mathrm{O}^{\mathrm{SM} 20(+)}$ & 172 & 139 & 81 \\
\hline $\mathrm{ZnO} \mathrm{O}^{\mathrm{SM} 20(-)}$ & 294 & & 47 \\
\hline $\mathrm{ZnO} \mathrm{AEI00(+)}^{\mathrm{A}}$ & 315 & 236 & 75 \\
\hline $\mathrm{ZnO} \mathrm{A}^{\mathrm{AE} 100(-)}$ & 339 & & 70 \\
\hline \multicolumn{4}{|l|}{ Size } \\
\hline $\mathrm{ZnO} \mathrm{O}^{\mathrm{SM} 20(-)}$ & 294 & 152 & 52 \\
\hline $\mathrm{ZnO} \mathrm{AEI00(-)}^{\mathrm{A}}$ & 339 & & 45 \\
\hline $\mathrm{ZnO} \mathrm{O}^{\mathrm{SM} 20(+)}$ & 172 & 97 & 56 \\
\hline $\mathrm{ZnO} \mathrm{O}^{\mathrm{AE} 100(+)}$ & 315 & & 31 \\
\hline
\end{tabular}

Abbreviations: $\mathrm{BH}$, brain homogenate; NPs, nanoparticles; $\mathrm{ZnO}$, zinc oxide. gins, ClueGO, which provided gene ontology and biological processes of the above proteins. Each biological process was symbolized with a circular dot, a representative processed datum (related to the number of proteins bound to a specific type of NP, written in large characters). Bound proteins from plasma with $\mathrm{ZnO}^{\mathrm{SM} 20(+)}$ seemed to associate with regulation of response to external stimulus, lipoprotein particle clearance, platelet activation, and wound healing (Figure 1A). Plasma proteins from lipoprotein particle clearance, complement activation, and wound healing were found from the adsorbed protein corona on $\mathrm{ZnO}^{\mathrm{SM} 20(-)}$ (Figure 1B). Commonly, plasma proteins in complement activation and wound healing were found in $100 \mathrm{~nm}$ protein corona of $\mathrm{ZnO}$ NPs (Figure 2A and B).

In the case of proteins from $\mathrm{BH}$, proteins bound with $\mathrm{ZnO}^{\mathrm{SM} 20(+)}$ were related to adenosine diphosphate biosynthetic process, regulation of actin polymerization or depolymerization, and complement activation (Figure 1C). $\mathrm{ZnO}^{\mathrm{SM} 20(-)}$ was determined to associate with proteins involved in proton transport, the nicotinamide metabolic process, regulation of actin polymerization or depolymerization, the glucose catabolic process, and neurotransmitter secretion (Figure 1D). For $\mathrm{ZnO}^{\mathrm{AE} 100(+)}$, proteins involved in the purine ribonucleoside triphosphate metabolic process, the nucleoside diphosphate metabolic process, regulation of axon diameter, the glutamate metabolic process, the nicotinamide metabolic process, and myofibril assembly were found on the surface of NPs (Figure 2C). The bound proteins to $\mathrm{ZnO}^{\mathrm{AE} 100(-)}$ revealed their associations in regulation of axonogenesis, acidic amino acid transport, proton transport, the nucleoside diphosphate metabolic process, the glutamate metabolic process, the glucose metabolic process, and the glucose catabolic process (Figure 2D).

\section{Discussion}

In a biological fluidic environment, such as plasma and cerebral spinal fluid, NPs may form complexes with various proteins, leading to a protein corona, which could transport or carry NPs to various organs and clearances. During the processes, NPs could interfere or perturb the original biological activity of the absorbed protein on the surface of the particles. Probing interactions between NPs and proteins from plasma in the protein's corona may help in understanding potential ramifications of NPs in various fluidic and biological environments, in addition to potential consequences due to changes in NPs physicochemical properties. Commonly, various NPs have the potential to bind with albumin, lipoprotein, acutephase protein, immunoglobulin, and the proteins associated 
A $20 \mathrm{~nm}(+)$ plasma

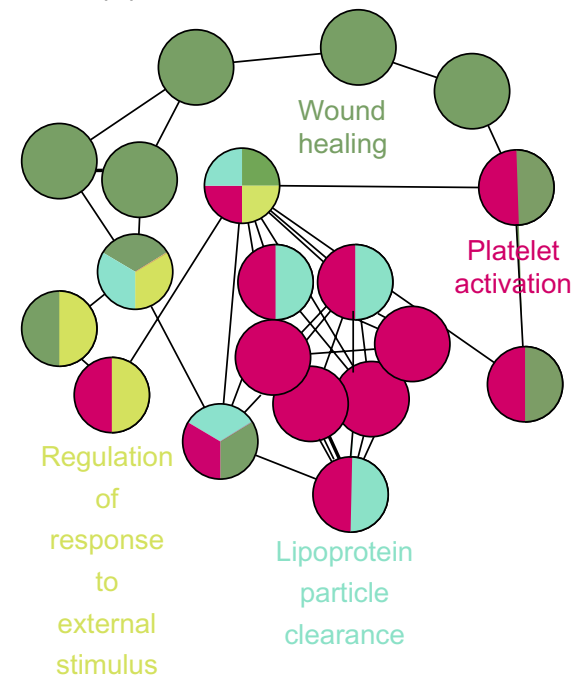

C $20 \mathrm{~nm}(+) \mathrm{BH}$

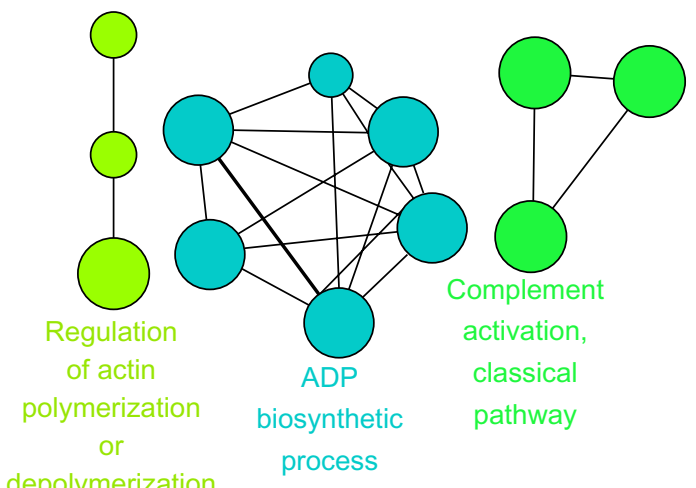

B $20 \mathrm{~nm}(-)$ plasma

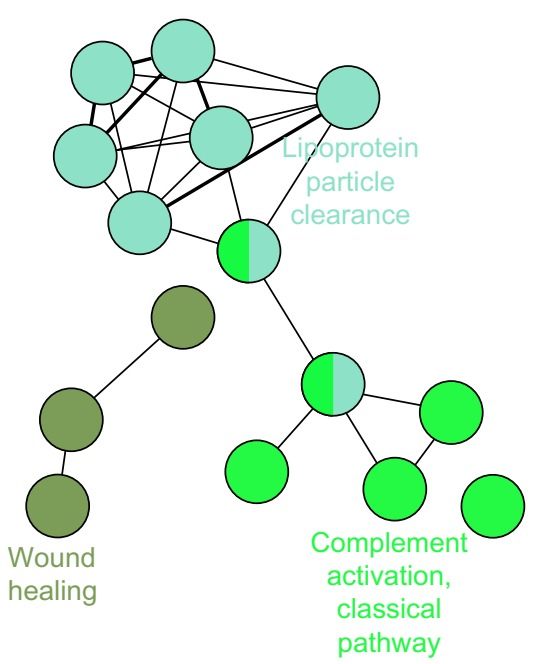

D $20 \mathrm{~nm}(-) \mathrm{BH}$

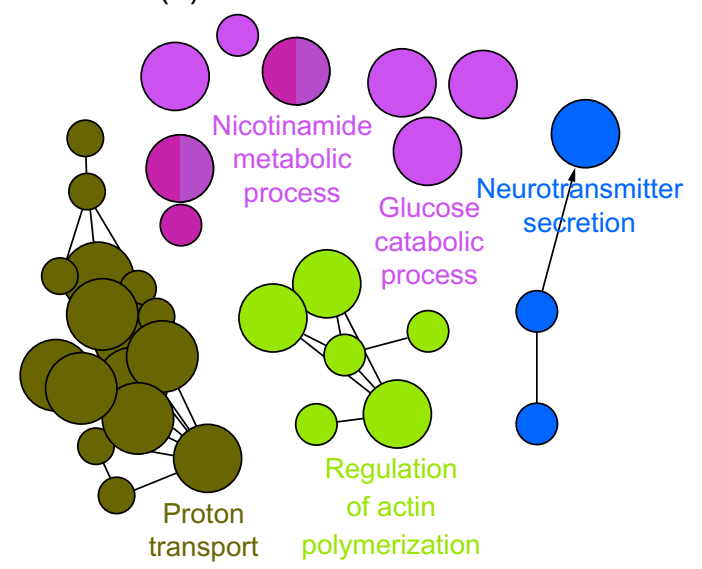

or

depolymerization

Figure I Visualized biological processes associated with ZnO NPs binding proteins of plasma and $\mathrm{BH}$.

Notes: (A) plasma, $20 \mathrm{~nm}(+)$; (B) plasma, $20 \mathrm{~nm}(-)$; (C) BH, $20 \mathrm{~nm}(+)$; (D) BH, $20 \mathrm{~nm}(-)$.

Abbreviations: $(+)$, positive; $(-)$, negative; $\mathrm{BH}$, brain homogenate; CoA, coenzyme A; NPs, nanoparticles; $\mathrm{ZnO}$, zinc oxide; RNA, ribonucleic acid.

with complement pathways and coagulation in the human plasma. Meanwhile, other proteins could specifically bind to NPs according to their properties, including size, surface charge, and shape. ${ }^{24,25}$ Additionally, when ZnO NPs are dissolved in the blood, a high concentration of ionic zinc could be generated. Hence, an in vitro test was conducted to differentiate the effects between ionic zinc and NPs. Although exposure to $\mathrm{ZnO}$ NPs induced apoptosis, the exposure of zinc chloride did not exhibited cytotoxic effect against U373MG cells. These results suggested that ionic zinc may not induce toxic effects in the blood (Jung-Eun Kim, personal communication, 2014).

From the current study, ZnO NPs mainly interacted with lipoprotein, acute-phase protein, and proteins in coagulation and complement pathways. Interestingly, ZnO NPs did not bind to albumin or immunoglobulin in the plasma, even though albumin or immunoglobulin depletions were not performed. It might seem that, since the compositions in the protein coronas could continuously exchange, $\mathrm{ZnO}$ NPs might have low affinity towards albumin or immunoglobulin, despite the high concentrations of albumin and immunoglobulin in plasma. As a result, albumin or immunoglobulin might have been easily replaced by other proteins with higher affinity, such as lipoprotein. On the other hand, lipoprotein, acute-phase protein, and proteins in coagulation and complement pathways seemed to bind strongly with all types of ZnO NPs in the plasma, and silica oxide NPs (Kyu Hwan Shim, personal communication, 2014). Through the 
A $100 \mathrm{~nm}(+)$ plasma

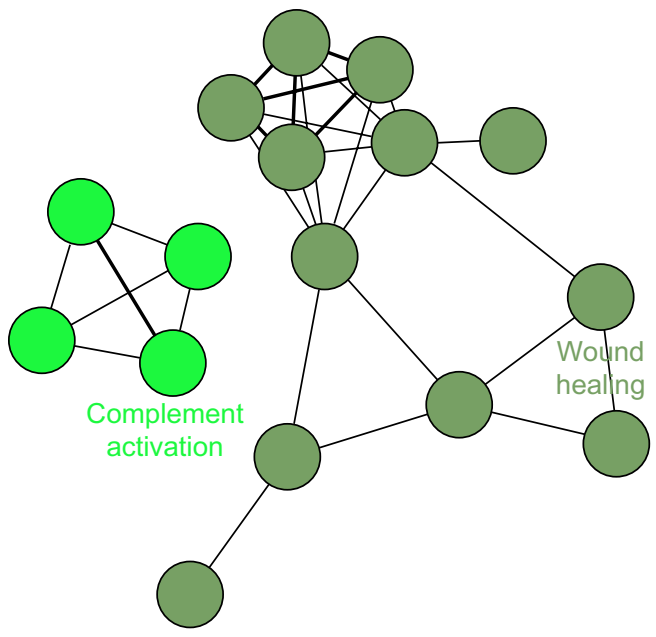

C $\quad 100 \mathrm{~nm}(+) \mathrm{BH}$

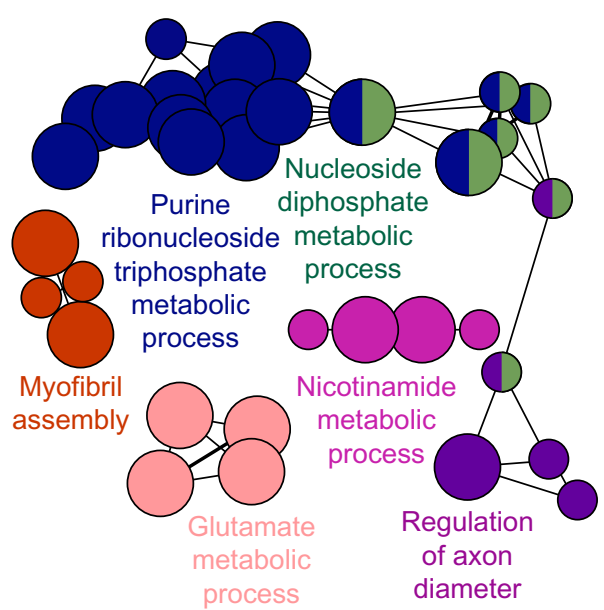

B $100 \mathrm{~nm} \mathrm{(-)} \mathrm{plasma}$

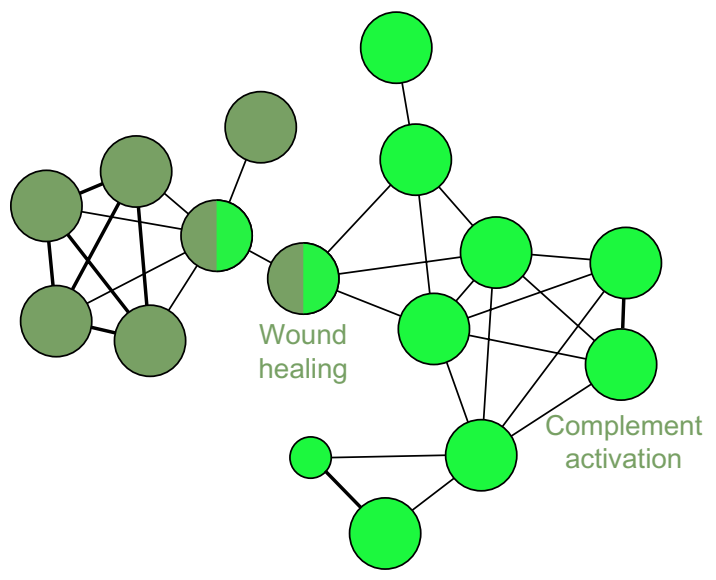

D $\quad 100 \mathrm{~nm}(-) \mathrm{BH}$

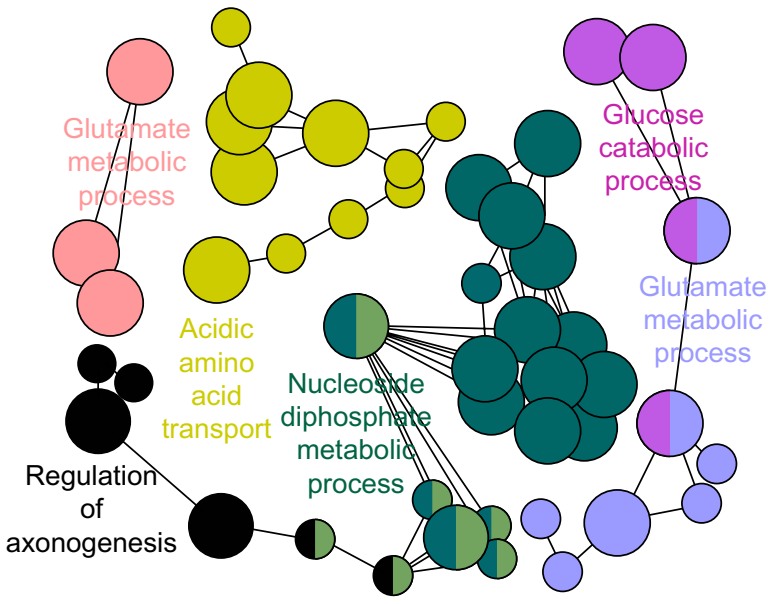

Figure 2 Visualized biological processed associated with ZnO NPs binding proteins of plasma and $\mathrm{BH}$.

Notes: (A) plasma, $100 \mathrm{~nm}(+)$; (B) plasma, $100 \mathrm{~nm}(-)$; (C) BH, $100 \mathrm{~nm}(+)$; (D) BH, $100 \mathrm{~nm}(-)$.

Abbreviations: (+), positive; (-), negative; $\mathrm{BH}$, brain homogenate; NPs, nanoparticles; ZnO, zinc oxide; ADP, adenosine diphosphate; RNA, ribonucleic acid

interactions between $\mathrm{ZnO}$ NPs and protein coronas, mechanisms of potential toxicity to clinical pathology could be speculated through the aforementioned biological processes in plasma as indicated in Figure 2A.

As mentioned before, NPs induced altered responses by disrupting protein conformation. ZnO NPs mainly bound to apolipoprotein, fibrinogen, and coagulation and inflammation factors in plasma, and to tubulin, heat shock protein, and ATP synthase in $\mathrm{BH}$ as indicated in Figure 2B. Thus, we focused on each protein to access possible toxic pathways after the adsorption on the NPs' surface. Apolipoprotein is the major component of lipoprotein and serves as enzyme cofactors, lipid transport, and in the regulation of lipid uptake in tissues. Some studies announced that apolipoprotein could be easily adsorbed to NPs through hydrophobic surfaces because of the flexible hinge region of the protein. ${ }^{26,27}$ Interestingly, apolipoprotein $\mathrm{E}$ was reported to interact with NPs, and it may play as a mediator of the NPs transportation across the BBB. ${ }^{28}$ The reports on apolipoprotein E supported that apolipoprotein might be an important protein in determining biological processes of the particles. Furthermore, fibrinogen is a plasma glycoprotein involved in coagulation, and is also one of the major proteins that binds with ZnO NPs. Not only does it play a role in blood coagulation, but also in the promotion of attachment for immune cells, such as macrophages, monocytes, and neutrophils, via binding to foreign surfaces. For example, the acute phase of the inflammatory response appeared to increase fibrinogen concentration. ${ }^{29}$ Fibrinogen specifically bound to the alpha-subunit of CK11/CD18 to activate neutrophils, it delayed apoptosis, and it enhanced 
phagocytosis and antibody-dependent cellular cytotoxicity. ${ }^{30}$ Fibrinogen and complement proteins were also in abundance on the surface of ZnO NPs in our results, such as previous studies. Previously, complement proteins bound to carbon nanotubes induced complement activation through both classical and alternative pathways. ${ }^{31} \mathrm{In}$ vivo study with $\mathrm{ZnO}$ through oral or tail vein administrations did not perturb the prothrombin time or activated partial thromboplastin time (Yu-Ri Kim, personal communication, 2014). Direct initiation of coagulation from contact activation by ZnO NPs will be studied in the near future by probing the prothrombin time and activated partial thromboplastin time in vitro with higher concentrations of $\mathrm{ZnO}$. On the other hand, after administration of ZnO NPs for 90 days, hematological and blood biochemical changes were observed (Yu-Ri Kim, personal communication, 2014). These changes might be induced by the interactions between proteins and NPs.

In case of bound proteins from brain on ZnO NPs, tubulin, heat shock protein, and adenosine triphosphate (ATP) synthase were major adsorbed proteins on all types of ZnO NPs. In previous studies, it has been suggested that the relationship between mitochondria dysfunction and reactive oxygen species production could be the main pathway in causing nanotoxic effects in various cell lines via mitochondria dysfunction, linked with ATP production..$^{32-36}$ Based on these results, NPs might be capable of causing toxic effects induced by mitochondria dysfunction by interacting with proteins in ATP production, especially within electron transport, such as ATP synthase. In addition, NPs inside the vacuole or cell could induce cytotoxic effects through interactions with tubulin, such as disrupting cytoskeletons and causing cell death. Previously, fullerene was reported to cause cell death from cytoskeleton disruption and autophagic vacuole accumulation. ${ }^{35}$ Regulation of actin polymerization or depolymerization was also involved with $\mathrm{ZnO}^{\text {SM20(-) }}$ and $\mathrm{ZnO}^{\mathrm{SM} 20(+)}$. Commonly, tubulin and heat shock protein were also found to bind tightly to all types of ZnO NPs. The full biological process in association with tubulin was not fully determined, and the number of proteins in this biological process was small. Heat shock protein was also found in the protein corona, which is involved in protein folding and unfolding. Nanotoxicity induced through heat shock proteins was not reported, but it was reported that NPs (copper, silver, or aluminum) enhanced whole body hyperthermia, inducing brain dysfunction depending on the physicochemical properties of the NPs. ${ }^{15}$ The expression of heat shock protein during whole body hyperthermia might be changed, which could be involved in neurological disease.
The biological processes of protein coronas were visualized depending on the properties of NPs and the biological fluids. Complement activation, lipoprotein particle clearance, and wound healing were commonly associated with all types of $\mathrm{ZnO}$ NPs in the plasma. ZnO NPs seemed to have a similar biological activity, irrespective of size and surface charge. However, as the similarity of protein coronas was low, detailed mechanisms should be different for each type of particle. As mentioned above, interactions between ZnO NPs and proteins in complement activation (complement factor), wound healing (fibrinogen), and lipoprotein particle clearance (apolipoprotein) could generate new biological activity and might induce abnormal biological responses. Even weak interactions between protein and $\mathrm{ZnO}$ NPs may result in conformational and functional changes in a size-dependent manner. ${ }^{37}$ These results support the theory that absorb bound proteins onto the surface of NPs may undergo conformational change, potentially developing reversible and irreversible configurations.

\section{Conclusion}

In this study, $\mathrm{ZnO}$ NPs were found to interact diversely with plasma and brain proteins, and they could potentially lead to toxic effects in various tissues, suggesting potential pathogenic mechanisms of ZnO NPs in the blood and brain. Moreover, binding interactions between proteins and $\mathrm{ZnO}$ NPs, forming protein corona, might affect the physiological functions through conformational changes as well as through inhibitory or enhanced enzymatic activities.

\section{Acknowledgments}

This research was supported by a grant (10182MFDS991) from the Ministry of Food and Drug Safety in 2010. This study was supported by a grant (2012R1A2A2A03046819) from the Korean National Research Foundation.

\section{Disclosure}

The authors report no conflicts of interest in this work.

\section{References}

1. Gerber C, Lang HP. How the doors to the nanoworld were opened. Nat Nanotechnol. 2006;1(1):3-5.

2. Ji S, Ye C. Synthesis, growth mechanism, and applications of zinc oxide nanomaterials. J Mater. Sci Technol. 2008;24(4):457-472.

3. Krug HF, Wick P. Nanotoxicology: an interdisciplinary challenge. Angew Chem Int Ed Engl. 2011;50(6):1260-1278.

4. Gojova A, Guo B, Kota RS, Rutledge JC, Kennedy IM, Barakat AI. Induction of inflammation in vascular endothelial cells by metal oxide nanoparticles: effect of particle composition. Environ Health Perspect. 2007;115(3):403-409.

5. Brunner TJ, Wick P, Manser P, et al. In vitro cytotoxicity of oxide nanoparticles: comparison to asbestos, silica, and the effect of particle solubility. Environ Sci Technol. 2006;40(14):4374-4381. 
6. Lee SH, Pie JE, Kim YR, Lee HR, Son SW, Kim MK. Effects of zinc oxide nanoparticles on gene expression profile in human keratinocytes. Mol Cell Toxicol. 2012;8(2):113-118.

7. Yeo MK, Park HG. Gene expression in zebrafish embryos following exposure to $\mathrm{Cu}$-doped $\mathrm{TiO} 2$ and pure $\mathrm{TiO} 2$ nanometer-sized photocatalysts. Mol Cell Toxicol. 2012;8(2):127-137.

8. Hanley C, Layne J, Punnoose A, et al. Preferential killing of cancer cells and activated human $\mathrm{T}$ cells using $\mathrm{ZnO}$ nanoparticles. Nanotechnology. 2008;19(29):295103.

9. Reddy KM, Feris K, Bell J, Wingett DG, Hanley C, Punnoose A. Selective toxicity of zinc oxide nanoparticles to prokaryotic and eukaryotic systems. Appl Phys Lett. 2007;90(213902):2139021-2139023.

10. Jang YS, Lee EY, Park YH, et al. The potential for skin irritation, phototoxicity, and sensitization of $\mathrm{ZnO}$ nanoparticles. Mol Cell Toxicol. 2012;8(2):171-177.

11. Win-Shwe TT, Fujimaki H. Nanoparticles and neurotoxicity. Int J Mol Sci. 2011;12(9):6267-6280.

12. Jeng HA, Swanson J. Toxicity of metal oxide nanoparticles in mammalian cells. J Environ Sci Health A Tox Hazard Subst Environ Eng. 2006;41(12):2699-2711.

13. Lai JC, Lai MB, Jandhyam S, et al. Exposure to titanium dioxide and other metallic oxide nanoparticles induces cytotoxicity on human neural cells and fibroblasts. Int J Nanomedicine. 2008;3(4):533-545.

14. Deng X, Luan Q, Chen W, et al. Nanosized zinc oxide particles induce neural stem cell apoptosis. Nanotechnology. 2009;20(11):115101.

15. Sharma HS, Sharma A. Nanoparticles aggravate heat stress induced cognitive deficits, blood-brain barrier disruption, edema formation and brain pathology. Prog Brain Res. 2007;162:245-273.

16. Oberdörster G, Maynard A, Donaldson K, et al. Principles for characterizing the potential human health effects from exposure to nanomaterials: elements of a screening strategy. Part Fibre Toxicol. 2005;2:8.

17. Yeo MK, Kang M. The biological toxicities of two crystalline phases and differential sizes of TiO2 nanoparticles during zebrafish embryogenesis development. Mol Cell Toxicol. 2012;8(4):317-326.

18. Park YH, Bae HC, Jang Y, et al. Effect of the size and surface charge of silica nanoparticles on cutaneous toxicity. Mol Cell Toxicol. 2013;9(1): 67-74.

19. Kroll A, Pillukat MH, Hahn D, Schnekenburger J. Current in vitro methods in nanoparticle risk assessment: Limitations and challenges. Eur J Pharm Biopharm. 2009;72(2):370-377.

20. Murdock RC, Braydich-Stolle L, Schrand AM, Schlager JJ, Hussain SM. Characterization of nanomaterial dispersion in solution prior to in vitro exposure using dynamic light scattering technique. Toxicol Sci. 2008;101(2):239-253.

21. Vertegel AA, Siegel RW, Dordick JS. Silica Nanoparticle size influences the structure and enzymatic activity of adsorbed lysozyme. Langmuir. 2004;20(16):6800-6807.

22. Linse S, Cabaleiro-Lago C, Xue WF, et al. Nucleation of protein fibrillation by nanoparticles. Proc Natl Acad Sci U S A. 2007;104(21): 8691-8696.
23. Kim KM, Kim TH, Kim HM, et al. Colloidal behaviors of $\mathrm{ZnO}$ nanoparticles in various aqueous media. Toxicol Environ Health Sci. 2012;4(2):121-131.

24. Lundqvist M, Stigler J, Elia G, Lynch I, Cedervall T, Dawson KA. Nanoparticle size and surface properties determine the protein corona with possible implications for biological impacts. Proc Natl Acad Sci US A. 2008;105(38):14265-14270.

25. Deng ZJ, Mortimer G, Schiller T, Musumeci A, Martin D, Minchin RF. Differential plasma protein binding to metal oxide nanoparticles. Nanotechnology. 2009;20(45):455101.

26. Cedervall T, Lynch I, Foy M, et al. Detailed identification of plasma proteins adsorbed on copolymer nanoparticles. Angew Chem Int Ed Engl. 2007;46(30):5754-5756.

27. Cushley RJ, Okon M. NMR studies of lipoprotein structure. Annu Rev Biophys Biomol Struct. 2002;31:177-206.

28. Kreuter J, Shamenkov D, Petrov V, et al. Apolipoprotein-mediated transport of nanoparticle-bound drugs across the blood-brain barrier. J Drug Target. 2002;10(4):317-325.

29. Kamath S, Lip GY. Fibrinogen: biochemistry, epidemiology and determinants. QJM. 2003;96(10):711-729.

30. Rubel C, Fernandez GC, Dran G, Bompadre MB, Isturiz MA, Palermo MS. Fibrinogen promotes neutrophil activation and delays apoptosis. J Immunol. 2001;166(3):2002-2010.

31. Salvador-Morales C, Flahaut E, Sim E, Sloan J, Green ML, Sim RB. Complement activation and protein adsorption by carbon nanotubes. Mol Immunol. 2006;43(3):193-201.

32. Xia T, Li N, Nel AE. Potential health impact of nanoparticles. Annu Rev Public Health. 2009;30:137-150.

33. Long TC, Saleh N, Tilton RD, Lowry GV, Veronesi B. Titanium dioxide (P25) produces reactive oxygen species in immortalized brain microglia (BV2): implications for nanoparticle neurotoxicity. Environ Sci Technol. 2006;40(14):4346-4352.

34. AshaRani PV, Low Kah Mun G, Hande MP, Valiyaveettil S. Cytotoxicity and genotoxicity of silver nanoparticles in human cells. ACS Nano. 2009;3(2):279-290.

35. Johnson-Lyles DN, Peifley K, Lockett S, et al. Fullerenol cytotoxicity in kidney cells is associated with cytoskeleton disruption, autophagic vacuole accumulation, and mitochondrial dysfunction. Toxicol Appl Pharmacol. 2010;248(3):249-258.

36. Foster KA, Galeffi F, Gerich FJ, Turner DA, Muller M. Optical and pharmacological tools to investigate the role of mitochondria during oxidative stress and neurodegeneration. Prog Neurobiol. 2006;79(3): 136-171.

37. Wang J, Jensen UB, Jensen GV, et al. Soft interactions at nanoparticles alter protein function and conformation in a size dependent manner. Nano Lett. 2011;11(11):4985-4991.
International Journal of Nanomedicine

\section{Publish your work in this journal}

The International Journal of Nanomedicine is an international, peerreviewed journal focusing on the application of nanotechnology in diagnostics, therapeutics, and drug delivery systems throughout the biomedical field. This journal is indexed on PubMed Central, MedLine, CAS, SciSearch $\AA$, Current Contents ${ } /$ Clinical Medicine,
Dovepress

Journal Citation Reports/Science Edition, EMBase, Scopus and the Elsevier Bibliographic databases. The manuscript management system is completely online and includes a very quick and fair peer-review system, which is all easy to use. Visit http://www.dovepress.com/ testimonials.php to read real quotes from published authors. 